ELORE (ISSN 1456-3010), vol. 18 - 1/2011.

Julkaisija: Suomen Kansantietouden Tutkijain Seura ry.

[http://www.elore.fi/arkisto/1_11/kirjat_stepanova.pdf]

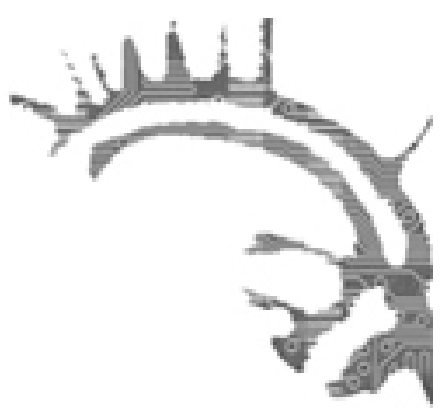

\title{
KIRJA-ARVIO
}

\section{VERTAILEVA TUTKIMUS KUOLINITKUISTA}

RAHIMOVA, ELINA 2010: "Tuonelskije svetšuški": slovesnaja izobrazitelnost karelo-finskih pritšitani po pokojnym. ['Tuonelan kynttiläiset": karjalais-suomalaisten kuolinitkujen sanallinen kuvaannollisuus']. Moskova: IMLI RAN. 237 sivua.

\section{Eila Stepanova}

Itämerensuomalaisia itkuvirsiä on tutkittu sekä Suomessa että Venäjällä melko vähän verrattuna esimerkiksi kalevalamittaiseen runouteen tai satuihin. Itkututkimus alkoi 1800-luvulla, ja se on siitä asti ollut yksittäisten, itkuvirsille omistautuneiden tutkijoiden varassa. Tästäkin huolimatta itkuvirret ovat olleet jatkuvasti läsnä erityisesti 1960-luvulta alkaen sekä venäläisellä että suomalaisella tutkimuskentällä, ja tutkijat ovat pohtineet muun muassa sitä, mitkä ovat itkuvirsitutkimuksen ensisijaiset ja keskeiset tutkimusongelmat ja -aineistot (Honko 1963; Konkka 1968). Esimerkiksi Unelma Konkka (1968, 175-181) on korostanut itkukielen ja eri paikallisten perinteiden vertailevaa tutkimusta. Petroskoissa vuonna 1979 järjestetyssä suomalais-venäläisessä symposiumissa, jonka teemana oli suomalais-ugrilainen ja pohjoisvenäläinen itkuvirsiperinne, Lauri Honko korosti itkuvirsien vertailevasta tutkimuksesta puhuessaan muiden kysymysten rinnalla motiivi- ja sanastovertailun, tuottamisen sääntöjen ja itkurakenteen tutkimuksen tärkeyttä (Honko 1979; ks. myös Honko 1963). Tunnettu venäläinen folkloristi ja itkuvirsitutkija Kirill Tšistov (1982, 104-105) taas on painottanut sitä, miten tärkeää tutkijoiden on kiinnittää huomiota suomalais-ugrilaisten ja venäläisten itkuperinteiden vertailuun. Vaikka eri itkuvirsiperinteiden vertailun tärkeyttä on korostettu, tällaista tutkimusta on tehty suhteellisen vähän.

Elina Rahimovan venäjänkielinen monografia "Tuonelan kynttiläiset": karjalais-suomalaisten kuolinitkujen sanallinen kuvaannollisuus käsittelee pääosin itämerensuomalaisia hautajaisten ja muistajaisseremonioiden yhteydessä esitettyjä kuolinitkuja ja käyttää vertailuaineistonaan sekä pohjoisvenäläisiä itkuja että kalevalamittaista runoutta. Monografia koostuu yhdestätoista luvusta, joista kolme ensimmäistä toimii johdantona 


\section{Eila Stepanova: Vertaileva tutkimus kuolinitkuista}

ja viisi seuraavaa käsittelee kuolinitkuihin liittyviä kielikuvia. Kolmessa viimeisessä luvussa kirjoittaja pohtii itkujen esittämistä, autenttisuutta, pysyvien kielikuvien säilymistä sekä itämerensuomalaisten ja pohjoisvenäläisten kuolinitkujen kielellisiä paralleeleja. Johtoajatus eri itkuperinteiden vertailusta verbaalisella ja semanttisella tasolla on oivallinen ja pitkään alalla odotettu, ja näin ollen Rahimovan monografia sijoittuu itkuvirsien tutkimuksen piiriin ja seuraa edellisen tutkijasukupolven viitoittamaa tietä. Olisi ollut hyvä, jos kirjoittaja olisi itse sijoittanut oman tutkimuksensa tähän laajempaan diskurssiin ja pohtinut, miten hänen tutkimuksensa liittyy Venäjällä ja Suomessa tällä hetkellä tekeillä olevaan itkuvirsitutkimukseen.

Johdantoluvuissaan Rahimova esittelee otsikon "Itkuvirsien elämän erityispiirteet ja keruuhistoria" alla itkuvirsien keruuhistorian vaiheita hyppien epäsystemaattisesti teemasta toiseen: kielihistoriasta kalevalamittaan ja itkuvirsiesimerkistä hyvin yksityiskohtaiseen keruuvaiheiden kuvailuun. Muun muassa Aleksandra Stepanova, Unelma Konkka ja Aili Nenola ovat laatineet perusteellisia selvityksiä itkuvirsien keruusta ja tutkimuksesta, mutta niitä ei valitettavasti ole hyödynnetty Rahimovan työssä (vrt. Stepanova \& Koski 1976, 5-25; Stepanova 2003, 4-27; Konkka 1992, 5-25; Nenola 2002, 32-35). Seuraava johdantoluku esittelee monografiassa käytetyn pääkorpuksen eli kaikki julkaistut itämerensuomalaiset itkuvirsitekstit. Sen sijaan tutkimuksen vertailuaineisto, pohjoisvenäläiset itkuvirret ja kalevalamittaiset runot, jäävät mainitsematta, eikä niiden luonnetta pohdita. Viimeinen johdantoluku kuvaa karjalais- ja inkeroisitkujen poetiikan ja semantiikan tutkimusta. Tämän luvun lopussa on esitetty lyhyesti tutkimuksen tavoitteet ja teoreettinen viitekehys mutta erityisesti tavoitteet jäävät epäselviksi, ja lukijan täytyy arvailla, mihin kirjoittaja tähtää.

\section{TEOreEtTISIA ONGELMIA}

Rahimova käyttää termejä ja käsitteitä melko rennolla otteella, mikä vaikeuttaa erityisesti etnopoetiikkaan ja formulateoriaan liittyvän teoreettisen kehyksen hahmottamista. Viktor Gatsakin luoma etnopoeettisen konstantin käsite on tutkimuksessa keskeinen mutta sen määrittely jää keskeneräiseksi. Rahimova luonnehtii konstantteja pysyviksi, visuaalisiksi mielikuviksi ("kuvaotoksiksi"), jotka vaikuttavat tekstien tuottamiseen ja vastaanottamiseen. Hän yhdistää nämä abstraktit visuaaliset kuvaotokset Michael N. Naglerin käsitteeseen preverbal Gestalt mutta sivuuttaa suullisen runouden formulaan liittyvän laajan keskustelun, josta Naglerin käsite on syntynyt ja johon se tiukasti liittyy. Lähdettä etsiessä paljastuu, että Rahimova viittaa Naglerin osalta tosiasiassa Joseph A. Russon kirjoittamaan artikkeliin, jossa esitetään kovaa kritiikkiä Naglerin preverbal Gestalt -käsitettä kohtaan. Russon mukaan Nagler ratkaisi formulan määrittelyn ongelman hävittämällä koko käsitteen. (Russo 1976, 34.)

Loppujen lopuksi lukijalle jää epäselväksi, miten etnopoeettisen konstantin käsite eroaa suullisen runouden formula-käsitteestä. Rahimova kirjoittaa: ”[..]verbaalinen konstantti eroaa periaatteellisesti M. Parryn ja A. B. Lordin määrittelemästä formulasta tai sellaisista perinteisemmistä käsitteistä kuten klisee ja loci communes. Ero ilmenee konstantin vartalon värähtelyssä samalla, kun sen ydin on pysyvä.” (s. 53.) Jäljempänä 
Eila Stepanova: Vertaileva tutkimus kuolinitkuista

konstantin ja formulan käsitteitä käytetään kuitenkin synonyymisesti (esim. s. 173, 178, 182). Myös käsitteet verbaaliset mikrokonstantit (s. 38), verbaaliset etnopoeettiset konstantit (s. 38-39), kompositionaaliset konstantit (s. 48), verbaalisten konstanttien nippu (s. 51), kiteytyneet sanalliset formulat (s. 182) ja kiteytyneet verbaaliset konstantit (s. 183) esiintyvät tekstissä tarkemmin määrittelemättä. Termien määrittely ja suhteuttaminen tieteelliseen keskusteluun olisi ollut paikallaan.

\section{Kuolinitkujen vainajat ja TuOnela}

Analyysiluvuissa Elina Rahimova käsittelee vainajaa ja hautaamista koskevia verbaalisia konstantteja karjalaisissa ja inkeriläisissä itkuissa sekä tuo esille runsaasti pohjoisvenäläisissä itkuvirsissä esiintyviä kielellisiä paralleeleja. Tällaisia ovat esimerkiksi kaikissa kolmessa itkuperinteessä esiintyvät motiivit ja pysyvät ilmaukset vainajan puhumattomuudesta. Itkijät voivat esimerkiksi esittää retorisia kysymyksiä vainajalle: "Miksi et puhu?", "Miksi olet hiljainen?", verrata vainajan puhumattomuutta aikaisempiin tapaamisiin tai pyytää vainajaa heräämään ja puhumaan. Rahimova on löytänyt venäläisistä itkuista erittäin mielenkiintoisen formulaisen ilmauksen (s. 65-67), jossa itkijä pyytää Luojaa tai enkeleitä antamaan vainajalle "jalkoihin kävelemistä, käsiin viittoilemista, kieleen puhumista". Vastaavaa ei löydy karjalaisista eikä inkeriläisistä itkuista. Rahimovan mukaan karjalaisissa ja pohjoisvenäläisissä kuolinitkuissa käytetään samantapaisia ylempien voimien valtaa käsitteleviä pysyviä ilmauksia (s. 60, 67). Toisin sanoen käsitys siitä, että vainajalla ei ole enää omaa valtaa vaan ylemmät voimat hallitsevat tilannetta, on yleinen. Käsitellessään itkijän ja vainajan välistä kommunikaatiota haudalla esitetyissä muisteluitkuissa Rahimova esittelee myös mielenkiintoisia havaintoja inkeriläisten itkujen ja lyyristen laulujen yhtäläisyyksistä. Niiden yhtenä paralleelisena konstanttina on vainajalle esitetty pyyntö nojata hautaristiin (s. 85-87).

Luvussa "Kaukainen Tuonela: sen olijat ja maiseman ja interiöörin esineelliset yksityiskohdat" kirjoittaja käsittelee karjalaisten ja inkeroisitkujen tuonpuoleista ja vainajan matkaa omien esi-isien luo. Tähän osioon on kerätty yhteen lukuisia esimerkkejä eri itkujen pysyvistä konstanteista, jotka koskevat Tuonelan tuntemattomia teitä, vainajaa vastaan tulevia esi-isiä ja niiden kantamia kynttilöitä (johon kirjan pääotsikko perustuu) tai vainajan mukana lähetettäviä terveisiä tuonpuoleisen väelle (s. 121-144). Valitettavasti Rahimova ei ole ottanut huomioon sitä, että tuonpuoleista koskevissa mielikuvissa on paitsi hyvin paljon yhtäläisyyksiä myös huomattavasti paikallisia eroja jopa yhden itkuperinteen sisällä esimerkiksi tuonpuoleisen nimityksissä ja kristinuskon vaikutuksessa.

\section{OMillaAN OLEVAN TUTKIJAN ONGELMia}

Kirjan tekstiesimerkkien runsaus häiritsee lukemista, minkä lisäksi Rahimovan esimerkeissä, erityisesti runsaimmin esiintyvissä karjalaisissa itkuissa, esiintyy toistuvasti virheitä: sanoja on jätetty pois tai ylimääräisiä sanoja ja äänteitä on lisätty, sanajärjestystä on muutettu, itkun säkeiden paikkaa on vaihdettu keskenään, äänteitä ja päätteitä 


\section{Eila Stepanova: Vertaileva tutkimus kuolinitkuista}

on kirjoitettu väärin. Tutkimuksesta löytyy myös hämmentävän paljon asiavirheitä viittauksissa, aineistossa ja käännöksissä. Esimerkiksi toisin kuin kirjoittaja esittää, yksi hänen keskeisimmistä aineistokokoelmistaan, Inkerin itkuvirret - Ingrian Laments (Nenola 2002), sisältää vajaat 700 eikä 4933 inkeriläistä itkua (s. 29) - 4933 on Aili Nenolan antama koodi kokoelmassa viimeisenä esiintyvälle itkutekstille.

Itkuvirsikieli on ylipäätään haastava käännettävä. Sille ominaiset lauserakenteet, kieliopilliset erikoispiirteet, runsas täytesanojen käyttö ja formulainen piilokieli vaativat vankkaa tuntemusta sekä koko perinteen että myös sen paikallisten piirteiden osalta. Rahimova mainitsee tehneensä käännökset itse, perustelematta kuitenkaan kääntämisen käytänteitään. Suurin osa kirjassa käytetyistä karjalaisten itkujen esimerkeistä on peräisin itkutekstikokoelmasta (Stepanova \& Koski 1976), jossa alkuperäisten tekstien rinnalla on julkaistu tarkat, Aleksandra Stepanovan tekemät venäjännökset. Osa Rahimovan käännöksistä poikkeaa näistä vain muutamien synonyymien osalta, jolloin on epäselvää, miksi ei olisi voitu käyttää jo olemassa olevaa käännöstä. Valtaosa Rahimovan käännöksistä vilisee virheitä, epätarkkuuksia ja epäjohdonmukaisuuksia. Niissä esimerkkitapauksissa, joissa kirjoittajalla ei ole ollut valmista venäjännöstä tukena, esiintyy virheitä, jotka joissain tapauksissa muuttavat itkun merkitystä. Esimerkiksi sivulla 165 "An'töta" (töta, ven. tjotja, 'täti') eli Anni-täti on Rahimovan käännöksen mukaan "Antoša". Tämä taas on Anton-nimen diminutiivinen hellittelymuoto, joten käännöksessä sekä itkijän sukupuoli että sosiaalinen asema ovat vaihtuneet.

Kirjaa lukiessa syntyy mielikuva, että kirjoittaja on tehnyt tutkimuksensa melkein täydessä tyhjiössä, koska työssä ei juuri viitata muiden tutkijoiden tutkimuksiin. Esimerkiksi alaluvussa "Tuskien tuulluttaminen", jossa käsitellään surusta eroon pääsemistä inkeriläisissä itkuissa, olisi ollut tarpeellista ottaa huomioon Senni Timosen (2004, 350-354) tulkinnat samasta motiivista. Vaikka Timosen tutkimukseen ei tekstissä viitata, se löytyy kuitenkin lähdeluettelosta. Kirjan lopussa taas Rahimova esittää olettamuksen, jonka mukaan verbaaliset konstantit voivat olla muistamis- ja esittämisprosessin tukena. Tämä olettamus on aika yleisesti tiedossa ja on ollut yksi suullis-formulaisen kompositioteorian perusteeseistä jo 1960-luvulta alkaen, jolloin on esimerkiksi todettu, että formulaisuus on yksi kerronnan tai esityksen jäsentelevistä apukeinoista (esim. Harvilahti 1992, 45; Lord 2001, 220-221). Suullisen runouden genreistä ja niiden poeettisista järjestelmistä käytävät keskustelut olisivat myös auttaneet Rahimovaa hänen tutkimuksessaan.

Rahimova on tehnyt ilmeisesti ison työn aineiston parissa, ja juuri tämä osoittautuu kirjan kompastuskiveksi: tulkinnat ja kantava ajatus hautautuvat satoihin aineistoesimerkkeihin. Kirjoittaja antaa aineiston puhua puolestaan, minkä vuoksi hänen omaa tutkijan ääntään ei kuulu. Kirjan taustalla oleva idea on itkuvirsitutkimuksen kannalta hyvin tärkeä ja aineistot ovat upeita. Valitettavasti tutkimuksen toteutuksen taso sekä asia- ja aineistovirheet vähentävät huomattavasti tutkimuksen uskottavuutta, ja niiden vuoksi tutkimuksen tulokset jäävät vaisuiksi. 
Eila Stepanova: Vertaileva tutkimus kuolinitkuista

\section{KiRJALLISUUS}

TŠISTOV, KIRILL 1982: Pritšitanija u slavjanskih i finno-ugorskih narodov (nekotoryje itogi i problemy). - Sokolova V. K. (toim.), Obrjady i obrjadovyj folklor. Moskva: Nauka.

HARVILAHTI, LAURI 1992: Kertovan runon keinot. Inkeriläisen runoepiikan tuottamisesta. Helsinki: SKS.

HONKO, LAURI 1963: Itkuvirsirunous. - Kuusi, Matti (toim.), Suomen kirjallisuns I. Helsinki: SKS.

HONKO, LAURI 1979: Itkuvirsien vertailevasta tutkimuksesta. Suomalais-ugrilainen ja pohjoisvenälä̈nen itkuvirsiperinne -symposiumi, Petroskoi. [julkaisematon esitelmä.]

KONKKA, UNELMA 1968: Karjalaisen itkuvirsirunouden tutkimuksen ongelmia. - Virittäjä 2.

KONKKA, UNELMA 1992: Poezija petšali. Petrozavodsk: Karelija.

LORD, ALBERT B. 2001: The Singer of Tales. Second Edition. Cambrige, London: Harvard University Press. [1960]

RUSSO, JOSEPH A. 1976: Is "Oral" or "Aural" Composition the Cause of Homer's Formulaic Style? - Stolz, Benjamin A. \& Shannon, Richard S. III (eds.), Oral Literature and the Formula. Ann Arbor: Center for the Coordination of Ancient and Modern Studies, The University of Michigan.

NENOLA, AILI 2002: Inkerin itkuvirret - Ingrian Laments. Helsinki: SKS.

STEPANOVA, A. S. \& KOSKI, T. A. (toim.) 1976: Karelskije pritšitanija. Petrozavodsk: Karelija.

STEPANOVA, A. S. 2003: Karelskije platši. Spetsifika žanra. Petrozavodsk: Periodika. TIMONEN, SENNI 2004: Minä, tila, tunne. Näkökulmia kalevalamittaiseen kansanlyriikekaan. Helsinki: SKS.

Filosofian maisteri Eila Stepanova valmistelee väitöskirjaa Helsingin yliopiston folkloristiikan oppiaineessa karjalaisesta itkuvirsiperinteestä. 